RAFA

\title{
The impact of employee competencies management as part of the human capital on the intellectual capital implementing process
}

Prof. Eng. Rafał Prusak Czestochowa University of Technology, Faculty of Production Engineering and Materials Technology, Department of Production Management and Logistic

\section{Introduction}

The modern market is subjected to the influence of several factors that affect planning and forecasting processes by high risk. The observed changes are often turbulent, have surprisingcourseand difficult to predictmacroand microeconomic consequences. Moreover, in many cases, these changes are caused by events and trends in seemingly industrially and geographically different sectors as the effect of not fully identified relationships and feedbacks. In these conditions, the key success factors are: the company's ability to quickly and correctly analyze the environment, the ability to appropriate assessment of its potential, ability to proper allocation of resources and using opportunities to build unique market advantages. In each of these aspects the correctness of actions depends on the level of human resources - especially in the quality context and the ability to transform these resources in human capital. In this area nowadays very important are intangibles recognized as the intellectual capital of the company - allowing for a clear distinction 
of enterprise's brand, product or quality from the competition equipped with similar technical facilities.

Available studies concerning human capital pay attention to many of its essential aspects. Specialist literature emphasizes that human capital is the combined knowledge, innovativeness (Edvisson, Malone 2001, p. 16), abilities, experience, creativity (Armstrong 2010, p. 129), social and personal skills (Lukasiewicz 2001, p. 139 ), features (physical, mental, intellectual and moral) formed by the predispositions and intrinsic motivation (Parsley-Otryl 2004, p. 216) of people permanently associated with the company who are able to cooperate (Sajkiewicz 2000, p. 17). At the same time the authors emphasize the complex structure of human capital pointing among its components: competency (knowledge and skills), motivation to use its potential and intellectual skills (using and increasing knowledge in practical operations) (Bratnicki 2001, p. 72), or - in other approach - abilities and behavior, effort and time (Lukasiewicz 2009, p. 19). The value of human capital largely depends on the level of involvement of employees, the extent to which they want and can use their own potential to achieve the objectives of the company. The key factor in this context is therefore to provide an adequate level of motivation and job satisfaction of employees, that may follow a synergistic impact of organizational culture, management style, conditions and content of work, relationships and incentives as part of the incentive system. The size of employee engagement affects the quality and strength of the relationship between the company and the relevant entities in its environment as well as the level of potential accumulated in enterprise resources - including the intangibles. It can be assumed that the intellectual capital depends on the human resources management strategy, although it is difficult to find in the specialist literature particular deterministic or probabilistic relationships. Reasons for this state should be sought primarily in the: complexity of the human being (it's difficult to know personality, size and level of knowledge resources and factors inspiring human behavior); complications resulting from the learning mechanisms (matching methods to the possibility of workers); difficulties in determining the degree of impact of training processes on the efficiency gains; problems related to financial valuation of intellectual capital, hindering the creation of easy-tointerpret economic indicators.

In the literature, intellectual capital is presented in an ambiguous and inhomogeneous way. Different researchers pay attention to different characteristics. It is emphasized that it is the sum of knowledge of humans gathered within the organization (Nahapiet, Ghosal 1998, p. 242), their competencies expressed in the manner of their way of thinking and working 
(Ulrich 1998, p. 16), hidden assets related to the gap between market value and book company (Edvisson, Malone 2001, p. 39) and is formed as a result of intellectual activities extending from the acquisition of new knowledge to the inventiveness to create relationships with other aspects of knowledge (Wiig 1997, p. 399) determining the market advantage (Stewart 1997, p. 13).

The role of people in the formation of intellectual capital is unquestionable. According to Sullivan human capital is an essential element of intellectual capital, precisely knowledge of workers, which - as a result of codifying - allows to create intellectual assets (Sullivan 2000, p. 16). Human is one of the primary sources of knowledge in the company, and has the ability of an independent or inspired development of knowledge as a result of aligning owned collection of practical information to the changing environment. The efficiency of these processes depends on the competencies held by the employees. The relationship between the competence of workers and intellectual capital is shown schematically in figure 1.

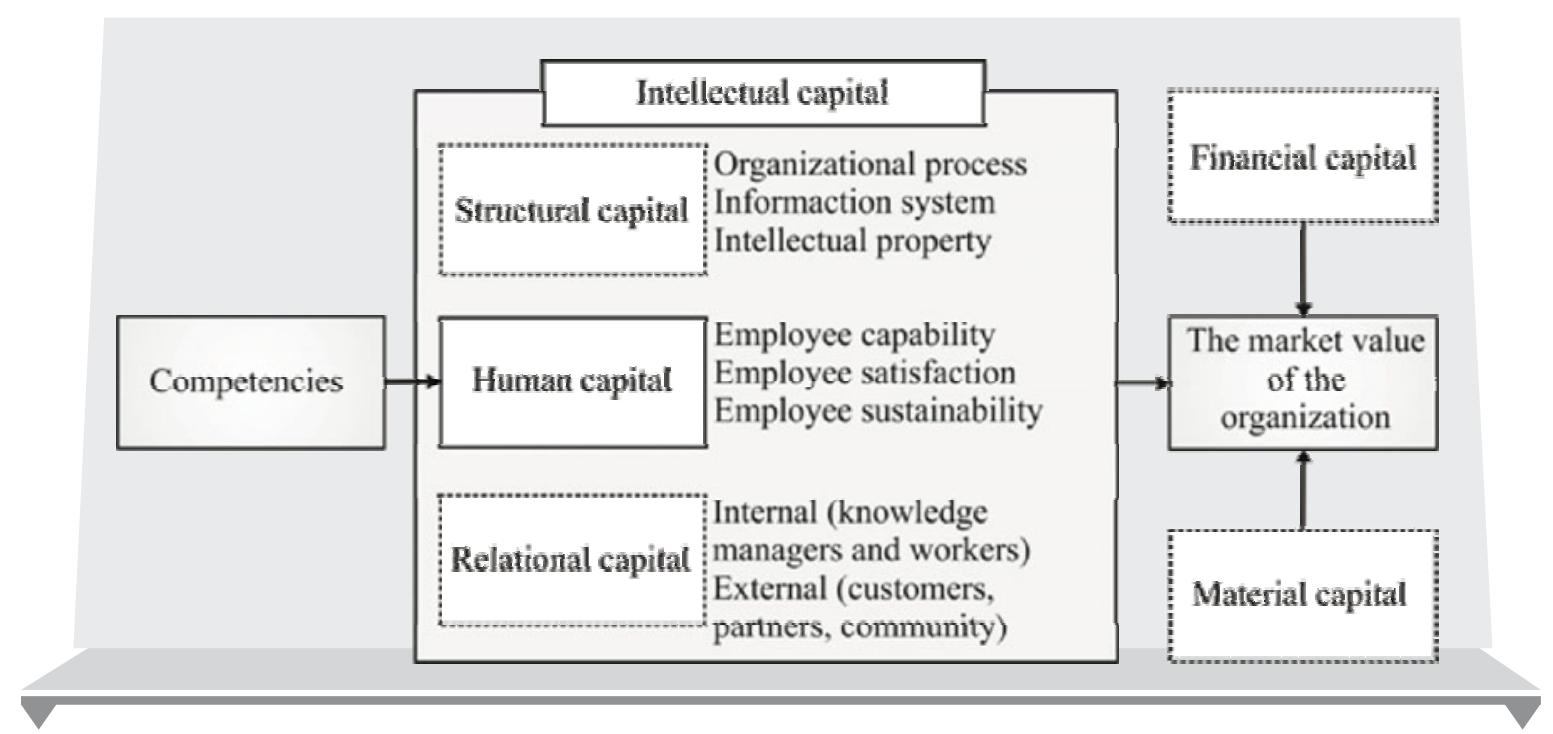

Figure 1. Competencies and the market value of the organization

Source based on: Walkowiak 2004, s. 16; Bukowitz, Williams 2000, p. 223; Moon, Kym 2006, s. 257, Chomiak-Orsa 2013, s. 108

The concept of competencies is fairly well studied and described in the literature. Widely emphasized is their role in the context of development, not only employees, but also the entire organization (Picket 1998, p. 103) because people based on their own knowledge and experience, create and modify the 
structures, methods, and techniques for more effective achievement of the strategic objectives (Abrahamsson 1990, p. 76) as well as create valuable interorganizational relationships which allow the development of both enterprise and stakeholders. The key factor determining the degree of utilization of individual competencies of particular person is the level of motivation and attitude to the designated tasks. From the point of view of the value of intellectual capital a lot of elements can have influence on the attitude of the employee, directly or indirectly related to the specific person. Direct factors, among others are: human personality traits, norms and values, social status and social role of the worker, the level of self-esteem, fulfillment of the professional and social ambitions and expectations. Indirect factors are: organizational culture, management style, the organization of work processes, the market image of the company, the condition of the country's economy, unemployment and others.

In order to increase the value of intellectual capital companies should, among other things, undertake a number of activities related to development of competencies of employees and the human resource management. The most important issues in this area are:

- synchronizing the objectives and actions intended to achieve - in the area of personnel strategy and management of intellectual capital,

- improving the recruitment and selection processes to hire employees with high potential, open to new ideas and concepts, capable of creative collaboration, maintain good relations and creating formal and informal contextual groups,

- implementation of flexible organizational structures supported by not autocratic, participatory management systems and properly constructed motivation systems that increase the level of employees involvement,

- implementation in the enterprise of mechanisms that increase the level of employees motivation to participate in development processes, acquisition of knowledge, continuous learning and search for new effective forms realization of assigned tasks.

The purpose of this study is to show the impact of management competence of employees, as part of human capital, on selected issues related to the implementation of intellectual capital. Within the empirical research selected linkages between competence and intellectual capital are shown.

\section{Analysis of results}

The results presented in this paper are part of a wider research on the formation and management of intellectual capital. The main analysis tool in the study was 
a questionnaire consisting of 23 questions. In addition, a strategic analysis was performed for determining the market position and potential of companies. A survey sample was 70 companies (20 small enterprises, 30 - medium-sized, 20 large; 37 production enterprises, 33 - service).

The primary empirical purpose of the study was to examine the correlation between the existence of enterprise competency management system (and its degree of integration with the overall strategy) and intellectual capital management process implementation and certain effects of its functioning.

In order to determine the role played by competence management system in enterprises a three-stage scale was used according to which the system could:

- be one of the elements of the personnel management system (1),

- be an important element in the personnel policy by taking part in setting goals and determining human resources needs (2),

- be an important element of enterprise management affecting not only personal issues but also providing information for strategic decisions (3).

To determine the degree of correlation the Pearson indicator and Chi-square test for the level of detail $\alpha=0,05$ were used.

The first stage of the research was to attempt to get an answer to the question whether the fact of implementation of enterprise competency management system affects the approach of managers to intellectual capital (fig. 2). The results allowed for conclusion that there is a clear correlation expressed by Pearson ratio value at 0.6 . The increase of the role of a competence management system in enterprises was accompanied by the increase of the importance of intellectual capital. The results can be considered consistent with expectations. Competence management system is one of the key elements of intellectual capital management and refers to the most important component of the capital - the people. Its existence gives managers the ability to analyze the company and its environment in a broader perspective, allowing the perception of new opportunities and possibilities offered by the further development of the management system with elements related to intellectual capital.

The next stage of the study was to investigate the relationship between the role of competence management system and causes of wider interest in intellectual capital (fig. 3). In this area, the study failed to statistically confirm the existence of a correlation, although it is possible to see some trends in the distribution of data. Companies in which the role of a competence management system was limited to personnel management indicated only one answer - the positive effects of similar activities with competitors. In addition, an answer related to the functioning in the industry in which knowledge is a key factor to compete 
was indicated only by the companies with widest meaning of competence management system. Very interesting data distribution was observed for companies declaring an average role of competence management system. Only in this group there were indications related to the answer "other", which in effect of in-depth analysis meant: globalization of operations, implementation of certified quality management systems, the willingness to more efficient use of human capital

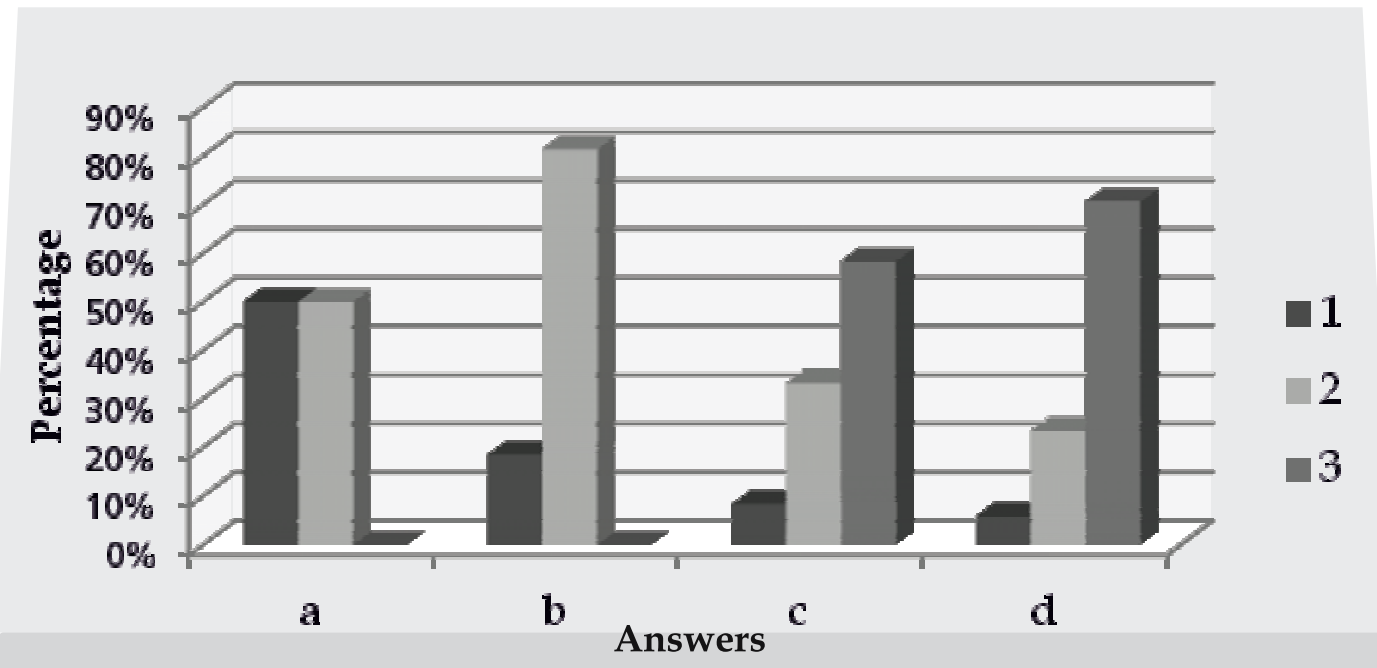

Figure 2. Percentage distribution of data describing the approach of managers of enterprises for the management of intellectual capital depending on the role of competence management system

The values on the $x$-axis means: a) lack of interest in intellectual capital, b) taking small actions without significant impact on the strategy, c) activities limited to the human management system, d) the strategic importance of intellectual capital

\section{Source: own study}

The complexity of the intellectual capital management system contributes to increasing importance of a number of other components of enterprise management, relations existing between them and feedbacks that can lead to a synergistic effect. The study subjected correlation between the role of competence management system and the nature of the elements that management staff indicates as key factors for the implementation of intellectual capital management mechanisms. As a result, there was found a clear correlation expressed by Pearson ratio value of 0.7. A closer analysis of the results revealed 


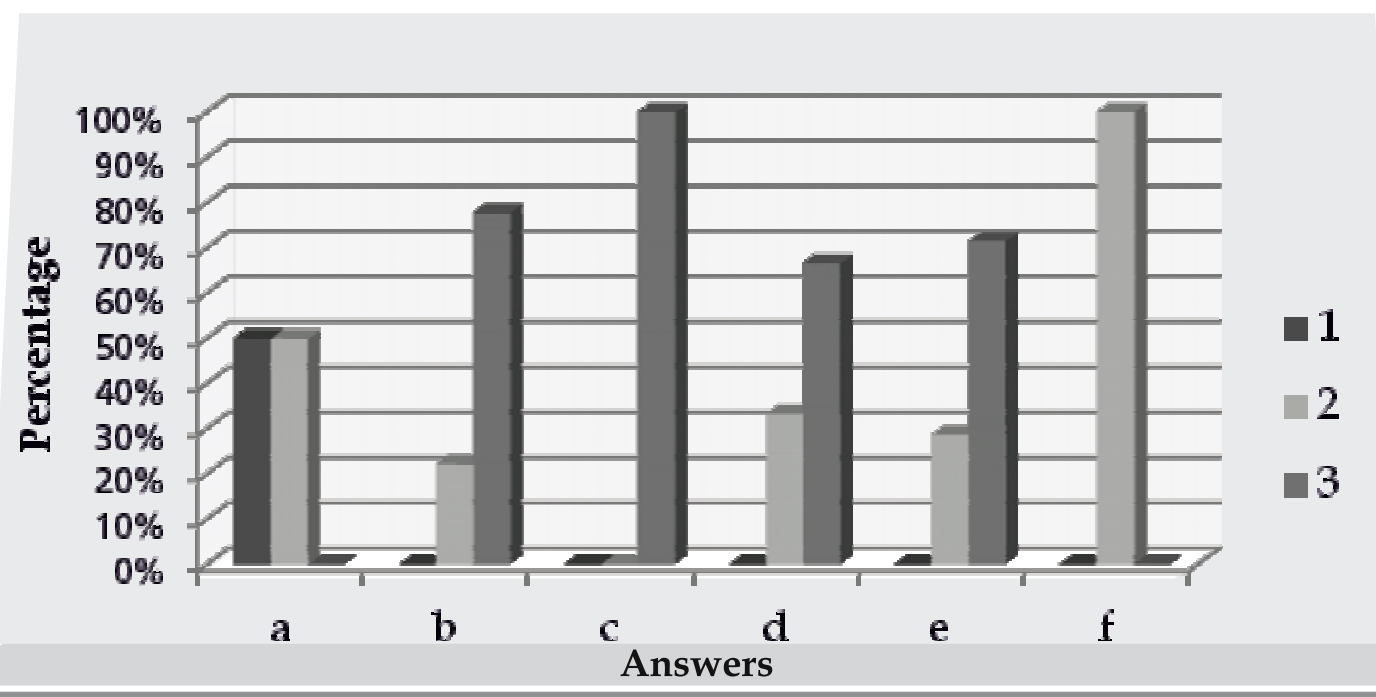

Figure 3. Percentage distribution of data describing the reasons for interest in intellectual capital management depending on the role of competence management system

The values on the $x$-axis means: a) the competitors positive effects of similar activities,

b) errors caused by difficulties in systematizing knowledge, c) operating in industry where knowledge is an essential factor in competition, d) deterioration of the enterprise market position as a result of outdated solutions, e) indications of an economic nature, $f$ ) other

Source: own study

Table 1. Percentage distribution of data describing the elements supporting the implementation of intellectual capital management depending on the role of competence management system

\begin{tabular}{r|r|r|r|r|r|r|r|r|r|r|r}
\hline & a & \multicolumn{1}{c|}{$\mathbf{b}$} & $\mathbf{c}$ & \multicolumn{1}{c|}{$\mathbf{d}$} & $\mathbf{c}$ & $\mathbf{f}$ & $\mathbf{g}$ & $\mathbf{h}$ & $\mathbf{i}$ & $\mathbf{j}$ & $\mathbf{k}$ \\
\hline $\mathbf{1}$ & $0 \%$ & $0 \%$ & $0 \%$ & $0 \%$ & $0 \%$ & $0 \%$ & $0 \%$ & $0 \%$ & $0 \%$ & $0 \%$ & $100 \%$ \\
\hline $\mathbf{2}$ & $0 \%$ & $33 \%$ & $0 \%$ & $50 \%$ & $0 \%$ & $33 \%$ & $100 \%$ & $100 \%$ & $50 \%$ & $0 \%$ & $0 \%$ \\
\hline $\mathbf{3}$ & $100 \%$ & $67 \%$ & $100 \%$ & $50 \%$ & $100 \%$ & $67 \%$ & $0 \%$ & $0 \%$ & $50 \%$ & $100 \%$ & $0 \%$ \\
\hline
\end{tabular}

The values on the $x$-axis means: a) the existence of a competence management system, b) strategic importance of personnel management system, c) the ability to use the experience of other enterprises, d) specialized external entities included in the process, e) highly qualified staff, f) high commitment of management, g) the involvement of employees, h) properly selected members of executive team, i) designation of the appropriate number of resources, j) IT solutions functioning in enterprise, k) other

Source: own study 
that only the companies in which competence management system has strategic role indicated items such as: the ability to use the experience of other companies, highly qualified staff and appropriate IT solutions (table 1).

An important element of the study was to determine the declared by management staff degree of preparedness for the implementation of intellectual capital management mechanisms. The analysis did not allow for finding any correlations in considered context of this study. Data distribution shows, however, that only companies in which competency management has a strategic role indicated that have extensive experience in implementing system solutions (fig. 4). This may suggest that a competence management system is often part of integrated management systems - although, no doubt - it should be more detail examined before the final conclusions.

The complexity and multifaceted intellectual capital result in significant variability of results obtained by different companies in effect of implementation of intellectual capital management systems. Depending on the level of knowledge, the nature of the industry or the priorities of the management staff two seemingly similar companies can get entirely different results. The study allowed to determine the correlation (Pearson ratio at 0.6) between the competence management system and the nature of the internal effects of the introduction of intellectual capital management mechanism. A very specific distribution of the data was obtained in the group of companies declaring that competency management system does not have an important role in overall strategy (table 2). Responses were focused on three effects: reducing the number of administrative and system errors, reducing the time of administrative activities and other (including: reducing staff turnover and reducing the number of stoppages).

\section{Conlusions}

Competencies are an important element determining the current professional potential of employees and its impact on intellectual capital. These result from participation in the educational process and the current life and work experiences. Activation of competence requires the existence of certain environmental conditions, stimuli and internal mental processes of the holder. The activities of the company, such as the design of effective motivation schemes and proper organization of work patterns have a huge impact on the utilization level of competence and efficiency of workers. Full utilization of the employee competence is only possible with adequate organizational solutions. 


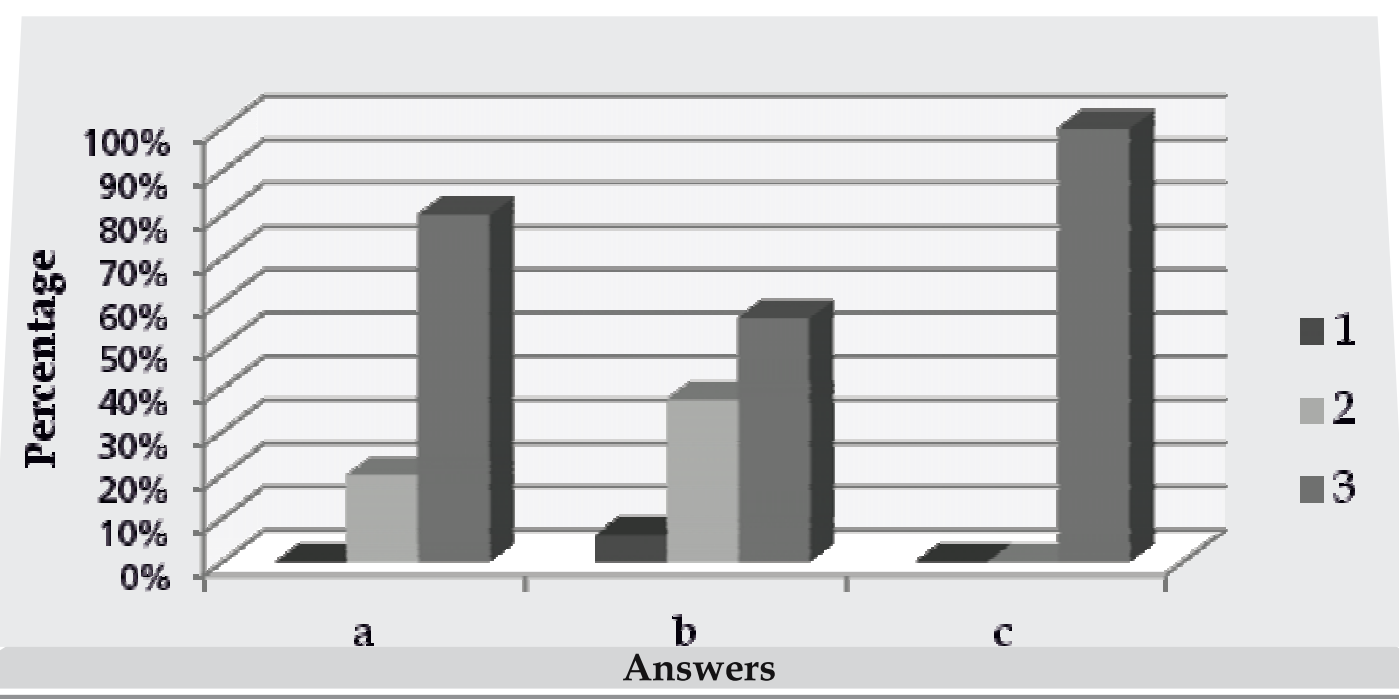

Figure 4. Percentage distribution of data describing the preparedness of the company to implement intellectual capital management depending on the role of competence management system

The values on the $x$-axis means: $a$ ) low (lack of experience in implementing of such systems), b) the average (experience in the implementation of some systems, but not related to intangible), c) high (company has repeatedly implemented a system solutions)

\section{Source: own study}

Table 2. Percentage distribution of data describing the benefits of an internal nature which are the result of the implementation of intellectual capital management mechanisms depending on the role of competence management system

\begin{tabular}{c|c|c|c|c|c|c|c|c|c|c|c|c|c}
\hline & $\mathbf{a}$ & $\mathbf{b}$ & $\mathbf{c}$ & $\mathbf{d}$ & $\mathbf{e}$ & $\mathbf{f}$ & $\mathbf{g}$ & $\mathbf{h}$ & $\mathbf{i}$ & $\mathbf{j}$ & $\mathbf{k}$ & $\mathbf{1}$ & $\mathbf{m}$ \\
\hline $\mathbf{1}$ & $0 \%$ & $0 \%$ & $0 \%$ & $0 \%$ & $0 \%$ & $0 \%$ & $0 \%$ & $0 \%$ & $0 \%$ & $25 \%$ & $50 \%$ & $0 \%$ & $100 \%$ \\
\hline $\mathbf{2}$ & $40 \%$ & $27 \%$ & $67 \%$ & $44 \%$ & $11 \%$ & $0 \%$ & $67 \%$ & $67 \%$ & $13 \%$ & $0 \%$ & $0 \%$ & $0 \%$ & $0 \%$ \\
\hline $\mathbf{3}$ & $60 \%$ & $73 \%$ & $33 \%$ & $56 \%$ & $89 \%$ & $100 \%$ & $33 \%$ & $33 \%$ & $88 \%$ & $75 \%$ & $50 \%$ & $100 \%$ & $0 \%$ \\
\hline
\end{tabular}

The values on the $x$-axis means: a) reducing the number of process errors, b) increasing the level of employees competences, $c$ ) increasing the market and the organization awareness of workers, d) increasing the level of employees job satisfaction, e) possession of unique knowhow, $\mathrm{f}$ ) an increase in the number of innovations, g) an increase in the activity of employees, h) increasing integration of employees, i) improving the quality of products, j) reducing the number of administrative and system errors, k) reducing the time of administrative activities,

l) improving the economic effects, m) other

Source: own study 
The employee must be properly aligned to the objectives and tasks of the workplace and has appropriately broad permissions. Competencies are not a homogeneous concept. There can be specific subgroups differently affecting the effectiveness of the organization and performance of the workers. Competence management system should then provide to identify the key elements most strongly associated with the implementation of strategic objectives.

The company expands owned intellectual capital throughout the entire period of its operation, not always doing this in a systematic and aware way. The probability of new solutions or improvements may, however, be increased by expanding the freedom of the presentation of ideas, optimizing the pace of work in a way assuring the time for a critical analysis of the activities, increasing fault tolerance to encourage employees to experiment and - above all - creating a management system that ensure compliance of organization objectives with the employees goals.

Results of the research presented in this paper apply only to a few selected aspects of the relationship between competence management and intellectual capital. The thematic scope of analysis is too narrow to be able to draw broader conclusions and generalizations. However, it allows to conclude several important phenomena. First of all, it enables the identification of clear correlation between the fact of the existence of the enterprise competency management system and the attitude of managers to intellectual capital. Moreover, an increase in the role of a competence management system contributed to the growth of interest in the management of other intangible assets. The study alsoa allowed to conclude that the level of the strategic role assigned to competence mnagement system affects the nature of the activities undertaken by the company in the implementation of intellectual capital management mechanisms. In this regard, there could be observed clear differences between the groups of companies expressed by a different distribution of accents and roles assigned to individual resources. A similar situation was also found in area of declared by management staff effects of the implementation of intellectual capital management mechanisms. It can be concluded that the impact of a competence management system and its role in strategic management of enterprises in the context of intangible assets and intellectual capital is clear and measurable It can be concluded that the impact of a competence management system and assigned it the role of strategic enterprises in the context of resource intangible and intellectual capital is clear and to some extent measurable. 


\section{Summary}

Analysis of the influence of a competence management system on the selected elements of the intellectual capital of enterprises Competencies of employees and competence management are elements fairly well described in the literature. A modern approach to these issues, however, must have a broader than traditional character. This follows the significant changes that took place in management sciences expressed by an increased role of intangible assets. Intellectual capital, its components, connections with enterprise resources and elements of the environment are an important aspects of the strategic considerations undertaken by management staff in modern enterprises. Competences - which are specific expression of the potential of employees, their ability to detect changes and finding solutions - in this new context become even more important. This study attempts to analyze the selected relationships between the competency management system, intellectual capital and the attitude to IC of management staff.

Key words: workers competencies, human capital, intellectual capital.

\section{Streszczenie}

Analiza wpływu systemu zarządzania kompetencjami na wybrane elementy kapitału intelektualnego przedsiębiorstw

Kompetencje pracowników oraz zarządzanie nimi są elementami dośc dobrze opisanymi w literaturze przedmiotu. Współczesne podejście do tych zagadnień musi jednak posiadać szerszy, od tradycyjnego, charakter. Wynika to z istotnych zmian wjekie miały miejsce w naukach o zarządzaniu wyrażających się wyraźnym zwiększeniem się roli zasobów niematerialnych. Kapitał intelektualny, jego elementy skłądowe, powiązania z zasobami przedsiębiorstwa oraz elementami otoczenia stanowią ważny element rozważań strategicznych podejmowanych przez kadry zarządzające nowoczesnych przedsiębiorstw. Kompetencje będące swoistym wyrazem potencjału pracowników, ich zdolności do dostrzegania zmian oraz znajdowania rozwiązań - $w$ tym nowym kontekście nabierają jeszcze większego znaczenia. W niniejszym opracowaniu podjęto próbe analizy wybranych relacji pomiędzy 
systemem zarządzania kompetencjamia kapitałem intelektualnym oraz nastawieniem do niego kadry kierowniczej.

\section{Słowa \\ kluczowe: $\quad$ kompetencje pracowników, kapitał ludzki, kapitał intelektualny.}

\section{References}

1. Abrahamsson K. (1990), Why organizations? How and Why people organize, CA Sage, Nebury Park.

2. Armstrong M. (2010), Strategiczne zarządzanie zasobami ludzkimi, Wolters Kluwer Polska, Warszawa.

3. Bratnicki M.,Strużyna J. (eds.) (2001), Przedsiębiorczość i kapitat intelektualny, Wydawnictwo Akademii Ekonomicznej w Katowicach, Katowice.

4. Bukowitz W.R., Williams R.L., The Knowledge management fieldbook, Financial Time, Prentice Hall, London 2000.

5. I. Chomiak-Orsa (2013), Zarzadzanie kapitałem relacyjnym w procesie wirtualizacji organizacji. Podejście modelowe, Wydawnictwo Uniwersytetu Ekonomicznego, Wrocław.

6. Edvinsson L., Malone M.S. (2001), Kapitał intelektualny, Wydawnictwo Naukowe PWN, Warszawa.

7. Jabłoński M. (2000), Koncepcja wartościowania kapitału intelektualnego w organizacji, [in:] Borowiecki R., Kwieciński M. (eds.), Informacja i wiedza $w$ zintegrowanym systemie zarzadzania, Kantor Wydawniczy Zakamycze, Zakamycze.

8. Juchnowicz M. (2007), Elastyczne zarządzanie kapitałem ludzkim w organizacji wiedzy, Difin, Warszawa.

9. Kasiewicz S., Rogowski W., Kicińska M. (2006), Kapitat intelektualny. Spojrzenie z perspektywy interesariuszy, Oficyna Ekonomiczna, Kraków.

10. Łukasiewicz G. (2001), Kapitat intelektualny w przedsiębiorstwie, [in:] Pocztowski A. (eds.), Kapitat intelektualny - dylematy I wyzwania, Wydawnictwo Wyższej Szkoły Biznesu, Nowy Sącz.

11. Łukasiewicz G. (2009), Kapitał ludzki organizacji. Pomiar i sprawozdawczość, PWN, Warszawa.

12. Moon Y.J., Kym H.G. (2006), A Model for the Value of Intellectual Capital, Canadian Journal of Administrative Sciences, vol. 23 (3).

13. Nahapiet Y., Ghosal S. (1998), Social Capital. Intellectual Capital and the Organizational Advantage, "Academy of Management Review", No. 2.

14. Picket L. (1998), Competencies and Managerial Effectiveness: Putting competencies to work, "Public Personnel Management", Vol. 27 (1).

15. Pietruszka-Otryl A. (2004), Wyzwania wartościowania kapitału intelektualnego organizacji, [in:] Skrzypek E. (ed.), Uwarunkowania sukcesu przedsiębiorstw w gospodarce opartej na wiedzy, Wydawnictwo UMCS w Lublinie, Lublin. 
16. Probst G., Raub S., Romhardt K. (2002), Zarzadzanie wiedza w organizacji, Oficyna Ekonomiczna, Kraków.

17. Sajkiewicz A. (ed.) (2000), Zasoby ludzkie w firmie, Wydawnictwo POLTEXT, Warszawa.

18. Stewart T.A. (1997), Intellectual Capital, Nicholas Brealey Publishing, London.

19. Sullivan P.H. (2000), Value-Driven Intellectual Capital, How to Convert Intangible Corporate Assets into Market Value, John Wiley \& Sons, Inc., New York.

20. Thierry D., Sauret C., Monod N. (1994), Zatrudnienie i kompetencje $w$ przedsiębiorstwie w procesie zmian, Poltext, Warszawa.

21. Urlich D. (1998), Intellectual Capital = Competency * Commitment, Sloan Management Review, No. 2.

22. Wiig K. (1997), Integrating Intellectual Capital with Knowledge Management, Long Range Planning, vol. 30 (3). 